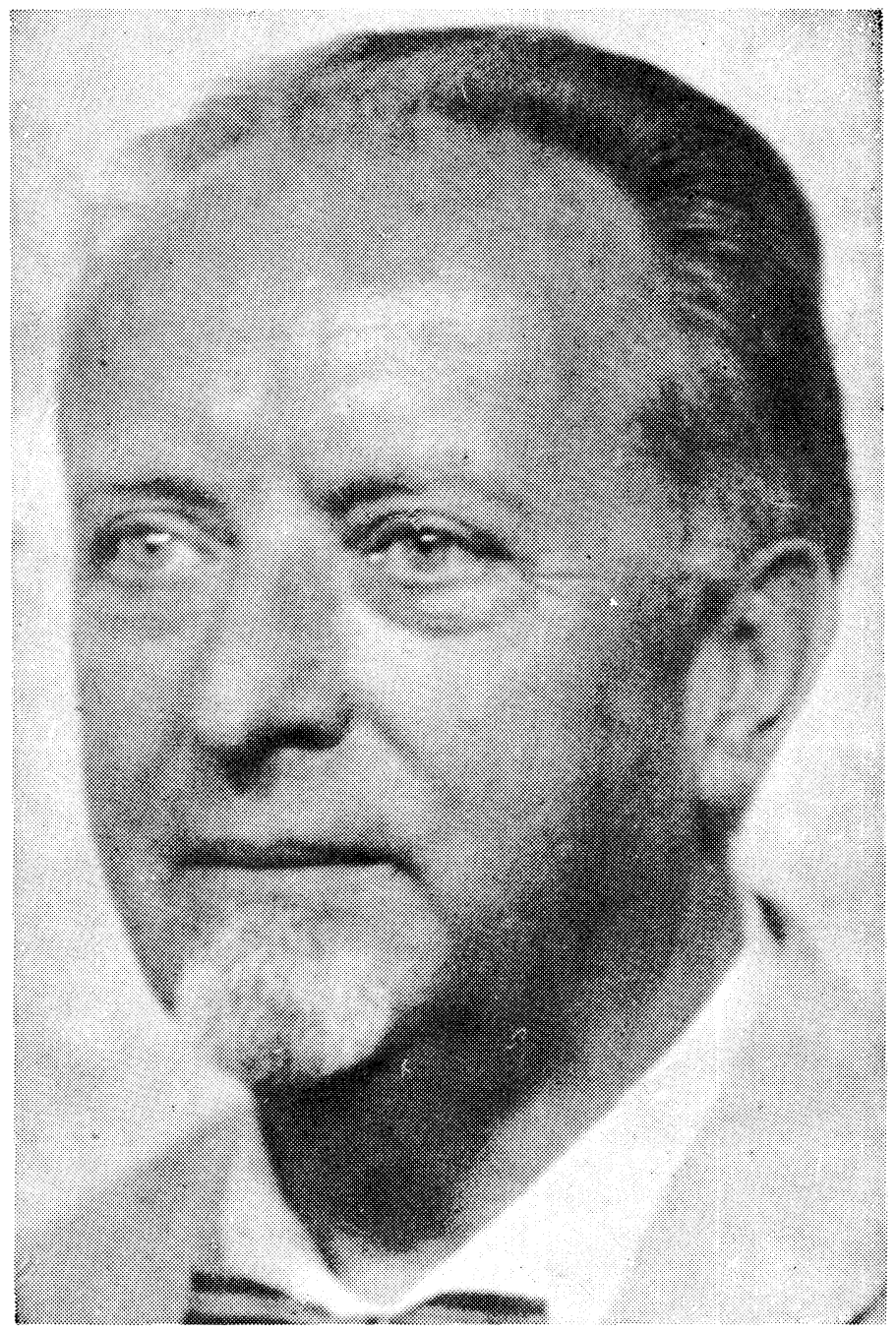

\title{
LEIF GARSDAL
}

8/12 1912-4/4 1974 


\section{Leif Garsdal}

Med kontorchef Leif Garsdal har Grundtvig-Selskabet mistet en af de støttepiller, intet solidt foretagende kan undvære. Allerede længe før han i 1967 indvalgtes i Selskabets styrelse som dettes kasserer, var det i realiteten Garsdal, der førte regnskabet for GrundtvigSelskabet og den af dette bestyrede Magnus Stevns' Mindefond. Han blev kontorchef for Kirkeligt Samfund 1. januar 1954 og førte fra 1. august 1955 også Grundtvig-Selskabets regnskab, der indtil da havde været varetaget først af pastor Morten Øllgaard og dernæst af fru Ellen Borup. Grundtvig-Selskabet har gennem hans person haft den lykke at have et nært og godt samarbejde med Kirkeligt Samfund, et samarbejde, der ikke er blevet afbrudt ved hans død. Siden højskoleforstander Ernst J. Borups og pastor Th. Balslevs død var kontorchef Garsdal faktisk Selskabets levende forbindelseslinie til arnestedet for den bevægelse, Grundtvig har begyndt.

Leif Garsdal var et menneske, hvis væsen var munterhed, et menneske som umiddelbart virkede indtagende. Men han havde samtidig et nøgternt blik for, hvad Grundtvig-Selskabets økonomi kunde bære. Den praktiske hjælp, han gennem kontoret i Vartov og rent personlig har ydet Grundtvig-Selskabet, er uvurderlig. Hans personlige kendskab til vore medlemmer var meget omfattende. Han kunde give - og gav gerne - stemningsrapporter om medlemmernes reaktioner, som fik betydning for de beslutninger, der blev truffet $\mathrm{i}$ forretningsudvalget, hvis møder han deltog i gennem alle de år, hvori han førte regnskabet.

Som leder af kontoret i Vartov fik Garsdal berøring med de mange Grundtvig-studerende, heriblandt udenlandske Grundtvigforskere, der besøgte Vartov og studerede i Grundtvig-Biblioteket. Højdepunktet i denne gren af hans virksomhed må det have været, da han i 1972 - som ved de foregående årsmøder - deltog i det praktiske arrangement af det internationale Grundtvig-Seminar i Helsingør. Han var en mand, hvis plads det er vanskeligt at udfylde.

William Michelsen 